\title{
RELATIONSHIPS BETWEEN MILK ELECTRICAL CONDUCTIVITY, DAILY MILK YIELD, AND MILKING ABILITY OF PRIMIPAROUS AND MULTIPAROUS COWS
}

\author{
I. Kuropatwińska ${ }^{1}$, M. Bogucki ${ }^{1}$, M. Miller ${ }^{2}$ and A. Sawa ${ }^{1}$ \\ ${ }^{1}$ Department of Animal Breeding, UTP University of Science and Technology, Mazowiecka 28, 85-084 Bydgoszcz, \\ Poland \\ ${ }^{2}$ Depatment of Molecular Biology, Institute of Genetics and Animal Breeding, Postępu 36 A, Jastrzębiec, 05-552 \\ Magdalenka, Poland \\ Correspondence to: Mariusz Bogucki (bogucki@utp.edu.pl)
}

\begin{abstract}
The new techniques for automation of the milking process allow for early diagnosis of mastitis. Diagnosis of subclinical mastitis should be a priority for every producer aiming to obtain raw milk of highest possible cytological quality. The analyses were performed based on herd milking data for Polish Holstein-Friesian cows yielding an average of $9500 \mathrm{~kg}$ milk. The herd consisted of 180 lactating cows, data from almost 152000 milkings were obtained. Correlations were calculated between milk electrical conductivity vs. daily yield and milking ability of primiparous and multiparous cows. The numerical data were statistically analysed using multifactorial analysis of variance. An increase in milk electrical conductivity and thus deteriorating udder health were paralleled by a significantly lower milk yield in both primiparous and multiparous cows. In primiparous cows, the decrease was $4.7 \mathrm{~kg}$ (from 32.0 with milk electrical conductivity of $\leq 5.50 \mathrm{mS} / \mathrm{cm}$ to $27.3 \mathrm{~kg}$ with conductivity of $>7.00 \mathrm{mS} / \mathrm{cm}$ ). A notably greater reduction in productivity was observed for multiparous cows $(5.5 \mathrm{~kg}$ ) between the extreme ranges of milk electrical conductivity. In both primiparous and multiparous cows, milking time increased progressively with increasing range of milk electrical conductivity (from 366 to $372 \mathrm{~s}$ and from 369 to $379 \mathrm{~s}$, respectively). Milk yield per minute decreased by $0.41 \mathrm{~kg}$ (from 2.23 to $1.82 \mathrm{~kg} / \mathrm{min}$.) in older cows and by $0.32 \mathrm{~kg}$ (from 2.05 to $1.73 \mathrm{~kg} / \mathrm{min}$.) in primiparous cows. The deteriorating udder health caused a significant decrease in daily milk yield of the primiparous and multiparous cows in every lactation period. For both primiparous and multiparous cows, the highest milk yields per minute $(2.08,2.20,2.20$ and 1.88; 2.57, 2.37, 2.18 and $1.96 \mathrm{~kg} / \mathrm{min}$., respectively) in all lactation periods were observed when milk electrical conductivity $(\leq 5.50 \mathrm{mS} / \mathrm{cm})$ was indicative of very good udder health. In summing up, it is concluded that throughout lactation, in both primiparous and multiparous cows, daily milk yield decreased with increasing electrical conductivity of the milk and thus with deteriorating udder health. Furthermore, milk electrical conductivity had a significant effect (in the interaction with lactation period and daily milk yield of the cows) on milkability traits.
\end{abstract}

Key words: cows, milk, electrical conductivity of milk, milking ability.

https://doi.org/10.36899/JAPS.2020.2.0044

Published online March 02, 2020

\section{INTRODUCTION}

Modern cow milking technology enables collecting more and more data concerning both animals and milk parameters on an ongoing basis. The new techniques for automation of the milking process allow for early diagnosis of mastitis, and play a significant role in analysing changes in milk composition and milk production from different udder quarters (Forsbäck et al., 2010; Jędruś, 2013). All of this information allows farmers to select the proper dairy management strategy, to make accurate selection decisions aiming to improve udder structure (elimination of cows with substandard milk production) and are important in preventing mastitis, which causes considerable economic losses (Atasever and Erdem, 2009).

One of the methods used to detect mastitis is to measure the electrical conductivity of milk. Under this method, cow mastitis is detected based on changes in mineral salts and lactose due to this disease. Importantly, the measurement of milk electrical conductivity allows clinical mastitis to be detected before changes in collected milk or udder tissue are visible. Conductivity measurements enable mastitis to be detected two or more milkings before visual signs appear (Norberg, 2005; Berglund et al., 2007). Changes in milk electrical conductivity, measured by instruments installed in the milking system, provide basic information for the computer herd management system. This system records milk conductivity data during each milking and shows the cows whose electrical conductivity differs from standards. In the presence of mastitis, electrical conductivity of milk increases due to increases in milk sodium and chlorine levels, and decreases in potassium and lactose, which are accompanied by increased $\mathrm{pH}$. The presence of sodium and chlorine has a positive effect on 
the value of electrical conductivity, because resistance and conductivity of a liquid depend on its composition and temperature (Bruckmaier et al., 2004). Also the presence of somatic cells as well as serum albumin changes the passage of an electric current through milk.

Milk from a healthy gland has an electrical conductivity of $4.00-5.50 \mathrm{mS} / \mathrm{cm}$ at $25^{\circ} \mathrm{C}$ (Yoshida et al., 2005). As reported by Park et al. (2007) and Ilie et al. (2010), milk with a temperature of $37^{\circ} \mathrm{C}$ drawn from a healthy cow has a conductivity from $4.54 \mathrm{mS} / \mathrm{cm}$, but with a deterioration in udder health it increases to 6.31 $\mathrm{mS} / \mathrm{cm}$ and above in clinical mastitis. According to Nowak et al. (1990), the correlation between milk electrical conductivity and the number of milk somatic cells is 0.91 .

Kasikci et al. (2012) report that early diagnosis of subclinical mastitis should be a priority for every producer aiming to obtain raw milk of highest possible cytological quality. Measurement of milk electrical conductivity is one of the indicators of such diagnosis, because it provides an early warning system by monitoring udder health at each milking.

The objective of the study was to determine the effect of milk electrical conductivity in automatically milked cows on their daily yield and milking ability, with consideration of their age and lactation period.

\section{MATERIALS AND METHODS}

The analyses were performed based on herd milking data for Polish Holstein-Friesian cows (Blackand-White variety) yielding an average of $9500 \mathrm{~kg}$ milk with $3.36 \%$ protein and $3.76 \%$ fat. The herd consisted of 180 lactating cows. Statistical analysis of the data included 59503 daily milking records (number of cows milked on a given day $\times 365$ days). With an average herd milking frequency of 2.55 times/day, data from almost 152000 milkings were obtained.

Cows were kept in a free-stall barn and received PMR and concentrate diets to meet the current maintenance and production requirements. The concentrate, which contained maize, soybean or rapeseed meal, triticale and premix, was offered from feeders in milking robots. Cows were milked by 3 automatic milking robots.

The data from the herd management system were used to calculate the following milking parameters of the cows:

- daily yield [kg milk], and milkability traits:

- milking duration [s],

- milk yield per cow [kg/min.].

The statistical analysis of these milking parameters accounted for:

- milk electrical conductivity $(\leq 5.50 \mathrm{mS} / \mathrm{cm}$ - healthy cows; $5.51-7.00 \mathrm{mS} / \mathrm{cm}$ - cows with elevated somatic cell count, early subclinical mastitis; $>7.00 \mathrm{mS} / \mathrm{cm}-$ subclinical mastitis and clinical mastitis),

- age of cows (primiparous, multiparous),

- period of lactation $(\leq 100,101-200,201-300,>300$

days),

- daily production level ( $\leq 25.0,25.1-35.0,>35.0 \mathrm{~kg})$.

Correlations were calculated between milk electrical conductivity vs. daily yield and milking ability of primiparous and multiparous cows. In addition, the effects of the milk electrical conductivity by lactation period interaction on daily yield and milkability of the cows, and of the electrical conductivity by daily yield interaction on milkability were determined.

The numerical data were statistically analysed using multifactorial analysis of variance (GLM procedure). Significant differences between the means were analysed with the Scheffe test (SAS, 2017).

\section{RESULTS AND DISCUSSION}

Earlier research indicates that milk obtained from healthy cows has an electrical conductivity of less than $5.50 \mathrm{mS} / \mathrm{cm}$ (Hillerton and Walton, 1991; Hamann and Gyodi, 2000). Based on this classification, milk from about $51 \%$ of the milkings was found to have an electrical conductivity below $\leq 5.50 \mathrm{mS} / \mathrm{cm}$, which means that it was collected from cows with healthy udders (Table 1). In the milk of healthy cows, somatic cell count is below 200 thous./ml. Schepers et al. (1997) consider this figure as the threshold value between healthy and diseased udder. Another $28.8 \%$ of milk samples had an electrical conductivity of $5.51-7.00 \mathrm{mS} / \mathrm{cm}$, indicating mild subclinical mastitis. In turn, $20.3 \%$ of the samples, grouped into the third class (milk electrical conductivity of $>7.00 \mathrm{mS} / \mathrm{cm}$ ) came from cows with advanced subclinical mastitis, or clinical mastitis. The close association of milk electrical conductivity with udder health and productivity was reported by Antanaitis et al. (2015). Milk electrical conductivity reached $6.50 \mathrm{mS} / \mathrm{cm}$ in cows with subclinical mastitis, $8.50 \mathrm{mS} / \mathrm{cm}$ during the period preceding the onset of clinical signs, and 9.0 $\mathrm{mS} / \mathrm{cm}$ after their manifestation. After treatment, the electrical conductivity of milk returned to normal levels.

The deteriorating udder health was accompanied by a considerable decrease in daily milk production $(\mathrm{p} \leq 0.01)$. The decrease was $6.9 \%$ between the first and second class of electrical conductivity (from 33.3 to 31.0 $\mathrm{kg}$ ), and $16.8 \%$ between the first and third class (from 33.3 to $27.7 \mathrm{~kg}$ ). For milkability parameters in successive ranges of milk electrical conductivity, milking time increased (from 366 to $378 \mathrm{~s}$ ) while the mean milk yield per minute decreased (from 2.15 to $1.73 \mathrm{~kg} / \mathrm{min}$.). Larroque et al. (2005) reported that milking time was related to udder health, with considerable differences in milking time between healthy and sick cows, especially those with clinical mastitis. According to the same authors, when milk electrical conductivity increases, the 
concomitant increase in mastitis has an adverse effect on the teats (teat canal, sphincter), thus decreasing the milk flow and increasing the milking time. Hillerton and Semmens (1999) suggest that milking time could also be a useful tool for mastitis detection.

In terms of the production level, older cows surpassed primiparous cows with the mean daily milk yield of 32.0 vs. $29.5 \mathrm{~kg}$ (Table 2). As milk electrical conductivity increased, daily milk yield decreased significantly $(\mathrm{p} \leq 0.01)$ in both primiparous and multiparous cows. In primiparous cows, the decrease was $4.7 \mathrm{~kg}$ (from $32.0 \mathrm{~kg}$ with milk electrical conductivity $\leq 5.50 \mathrm{mS} / \mathrm{cm}$ to $27.3 \mathrm{~kg}$ with conductivity $>7.00 \mathrm{mS} / \mathrm{cm}$ ). Multiparous cows showed a clearly higher decrease in milk yield $(5.5 \mathrm{~kg}$ between the extreme ranges of milk electrical conductivity).

According to Hovinen and Pyorali (2011), the lower milk production associated with mastitis problems in automatic milking systems, is due, among others, to the fact that the teats are cleaned without the visual control of the milker and mastitis is automatically detected.

Our study showed that udder health, determined by milk electrical conductivity, has a significant effect on milking time (Table 2). In both primiparous and multiparous cows, milking time increased with the increasing ranges of milk electrical conductivity (from 366 to $372 \mathrm{~s}$ and from 369 to $379 \mathrm{~s}$, respectively).

The milkability parameter of mean milk yield per minute was found to decrease with the increasing ranges of milk electrical conductivity. It decreased by $0.41 \mathrm{~kg} / \mathrm{min}$. in older cows (from 2.23 to $1.82 \mathrm{~kg} / \mathrm{min}$.), and by $0.32 \mathrm{~kg} / \mathrm{min}$. in primiparous cows (from 2.05 to $1.73 \mathrm{~kg} / \mathrm{min}$.).

According to Weiss et al. (2004), milk flow (peak or per unit of time) is influenced, to a certain extent, by the anatomical and functional characteristics of the teats.

The deteriorating udder health, which was determined based on milk electrical conductivity, caused a statistically significant $(\mathrm{p} \leq 0.01)$ decrease in daily milk yield of primiparous and multiparous cows in each lactation period (Table 3). The highest decrease in daily milk yield (by $4.1 \mathrm{~kg}$ ) was observed in primiparous cows in the third lactation period (from $31.6 \mathrm{~kg}$ with milk electrical conductivity $\leq 5.50 \mathrm{mS} / \mathrm{cm}$ to $27.5 \mathrm{~kg}$ with conductivity $>7.00 \mathrm{mS} / \mathrm{cm}$ ). In the other lactation periods, as udder health deteriorated, the cows' milk yield decreased by $1.8 \mathrm{~kg}$ (beginning of lactation) to $2.3 \mathrm{~kg}$ (end of lactation). More rapid changes in daily milk yield were noted in the multiparous cows. In each lactation period, the increase in milk electrical conductivity was paralleled by a more than $10 \%$ reduction in milk yield. It is worth noting that the lowest decrease (from 29.2 to $26.2 \mathrm{~kg}$ milk) occurred in multiparous cows between 201 and 300 days of lactation, whereas in primiparous cows it was the highest during this period. Among multiparous cows, cows in the final stage of lactation showed the most marked response to the deteriorating udder health. Their daily milk yield decreased by more than $20 \%$, from 24.2 to 18.8 .

These results, which show that deteriorating udder health entails milk production losses (from the very beginning of lactation) in both primiparous and multiparous cows, provide evidence that it is economically important for cows to start out their lactations with healthy udders. For this to happen, the health status of udders in in-calf heifers and multiparous cows should be closely monitored during the dry period.

Regardless of the lactation period, milking time varied $(p \leq 0.01)$ according to milk electrical conductivity. In each lactation period, milking time increased with deteriorating udder health, with cows entering lactation showing the longest milking time (360, 382 and $388 \mathrm{~s}$, respectively); in this group, the longest milking time of primiparous cows (388 s) and at the same time the highest increase in milking time (by $28 \mathrm{~s}$ ) were found (Table 3). It is worth adding that the shortest milking time (354 s) in primiparous cows was noted in the last period of lactation and in the first class of milk electrical conductivity. In primiparous cows, milking time in successive lactation periods also increased with the increasing electrical conductivity of milk. For cows entering lactation, milking time showed the smallest increase (by $14 \mathrm{~s}$, from 387 to $401 \mathrm{~s}$ ), whereas for cows between 201 and 300 days of lactation, it increased the most (by $20 \mathrm{~s}$, from 359 to $379 \mathrm{~s}$ ). In multiparous cows, the shortest milking time in all lactation periods (344 s) was noted in late lactation cows in the milk electric conductivity class of $\leq 5.50 \mathrm{mS} / \mathrm{cm}$.

Edwards et al. (2014), who thoroughly examined cow milking time at every stage of lactation, reported the longest time (416 s) at the beginning, and the shortest time (316 s) towards the end of lactation (days 241-300).

For both primiparous and multiparous cows, the highest milk yields per minute in all lactation periods $(2.08,2.20,2.20$ and $1.88 ; 2.57,2.37,2.18$ and $1.96 \mathrm{~kg}$ milk/min., respectively) were observed when milk electrical conductivity $(\leq 5.50 \mathrm{mS} / \mathrm{cm})$ was indicative of very good udder health. As lactation progressed and udder health deteriorated, this parameter gradually decreased. The decrease in mean milk yield per minute within the lactation groups was $0.25-0.36 \mathrm{~kg} / \mathrm{min}$. in primiparous cows and $0.41-0.55 \mathrm{~kg} / \mathrm{min}$. in multiparous cows

In addition to the milk yield and milk quality in its broad definition, milking speed is an important parameter with regard to milk production profitability (Sivarajasingam et al., 1984). The mean milk yield per minute, obtained in our study for primiparous and multiparous cows (during the first two lactation periods 
and with udder health determined by milk electrical conductivity of $\leq 5.50$ and $5.51-7.00 \mathrm{mS} / \mathrm{cm}-$ Table 3 ), correspond with earlier research findings (Lee and Choudhary, 2006; Bogucki and Neja, 2008; Sitkowska et al., 2015).

Analysis of the results given in Table 4 shows that the milking time of the cows increased with deteriorating udder health - by 12,12 and $14 \mathrm{~s}$ in primiparous cows, and by 17,18 and $20 \mathrm{~s}$ in multiparous cows $(\mathrm{p} \leq 0.01)$ in successive milk yield classes. In each daily milk yield class, the increase in electrical conductivity was accompanied by a decrease in the mean daily milk yield, which was the highest in cows with the highest production potential $(>35.0 \mathrm{~kg}$ milk/day) - by 0.19 and $0.37 \mathrm{~kg} / \mathrm{min}$, respectively. It should be mentioned that the highest stability of this milking parameter was observed in primiparous and multiparous cows when their daily milk yield ranged between 25.1 and $35.0 \mathrm{~kg}$.

The presented results (Tables 1,2 and 3) clearly show that the increase in milk electrical conductivity (which reflects deteriorating udder health) throughout the lactation of primiparous and multiparous cows generates milk production losses, resulting mainly from reduced milk yields of the cows. Not without significance are also the deteriorating milk yield parameters (milking time, mean yield per minute), which have a direct effect on milking ability of the cows. Therefore, breeders and milk producers should monitor udder health of the cows on an ongoing basis (among others, by determining the electrical conductivity of milk) so as to minimize the proportion of cows with subclinical or clinical mastitis.

Table 1. Effect of milk electrical conductivity on cows' milk yield and milkability

\begin{tabular}{cccc}
\hline Traits & \multicolumn{3}{c}{ Milk electrical conductivity [mS/cm] } \\
\cline { 2 - 4 } & $\mathbf{5 . 5 0}$ & $\mathbf{5 . 5 1 - 7 . 0 0}$ & $\mathbf{7 . 0 0}$ \\
\hline N (\%) & $30297(50.9)$ & $17108(28.8)$ & $12098(20.3)$ \\
Daily milk yield $[\mathrm{kg}]$ & $33.3^{\mathrm{AB}}$ & $31.0^{\mathrm{AC}}$ & $27.7^{\mathrm{BC}}$ \\
Milking time $[\mathrm{s}]$ & $366^{\mathrm{AB}}$ & $373^{\mathrm{AC}}$ & $378^{\mathrm{BC}}$ \\
Milk yield per minute $[\mathrm{kg} / \mathrm{min}]$ & $2.15^{\mathrm{AB}}$ & $1.94^{\mathrm{AC}}$ & $1.73^{\mathrm{BC}}$ \\
\hline
\end{tabular}

Means within lines followed by the same letters differ significantly at $P \leq 0.01$

Table 2. Effect of milk electrical conductivity on daily milk yield and milkability of primiparous and multiparous cows.

\begin{tabular}{clccccc}
\hline Age of cows & \multicolumn{1}{c}{$\begin{array}{c}\text { Milk electrical } \\
\text { conductivity [mS/cm] }\end{array}$} & $\mathbf{N}$ & & $\begin{array}{c}\text { Daily milk } \\
\text { yield [kg] }\end{array}$ & $\begin{array}{c}\text { Milking time } \\
\text { [s] }\end{array}$ & $\begin{array}{c}\text { Milk yield per } \\
\text { minute [kg/min] }\end{array}$ \\
\hline \multirow{3}{*}{ Primiparous } & $\leq 5.50$ & 16240 & 1 & 32.0 & 366 & 2.05 \\
& $5.51-7.00$ & 8945 & 2 & 29.1 & 369 & 1.86 \\
& $>7.00$ & 5372 & 3 & 27.3 & 372 & 1.73 \\
& Significance of differences & & & $1-2,3^{\mathrm{xx}} ; 2-3^{\mathrm{xx}}$ & $1-2,3^{\mathrm{xx}} ; 2-3^{\mathrm{xx}}$ & $1-2,3^{\mathrm{xx}} ; 2-3^{\mathrm{xx}}$ \\
& $\leq 5.50$ & 14057 & 1 & 34.6 & 369 & 2.23 \\
Multiparous & $5.51-7.00$ & 8163 & 2 & 32.2 & 375 & 2.06 \\
& $>7.00$ & 6726 & 3 & 29.1 & 379 & 1.82 \\
& Significance of differences & & & $1-2,3^{\mathrm{xx}} ; 2-3^{\mathrm{xx}}$ & $1,2-3^{\mathrm{xx}} ; 2-3^{\mathrm{xx}}$ & $1-2,3^{\mathrm{xx}} ; 2-3^{\mathrm{xx}}$ \\
\hline
\end{tabular}

$\mathrm{xx}_{P \leq 0.01}$

Table 3. Effect of milk electrical conductivity and lactation period on daily milk yield and milkability of primiparous and multiparous cows.

\begin{tabular}{|c|c|c|c|c|c|c|c|}
\hline Age of cows & $\begin{array}{c}\text { Lactation } \\
\text { period } \\
\text { [days] }\end{array}$ & $\begin{array}{c}\text { Milk electrical } \\
\text { conductivity } \\
{[\mathrm{mS} / \mathrm{cm}]}\end{array}$ & \multicolumn{2}{|c|}{$\mathbf{N}$} & $\begin{array}{c}\text { Daily milk } \\
\text { yield [kg] }\end{array}$ & $\begin{array}{l}\text { Milking time } \\
{[\mathrm{s}]}\end{array}$ & $\begin{array}{c}\text { Milk yield } \\
\text { per minute } \\
\text { [kg/min] }\end{array}$ \\
\hline \multirow{7}{*}{ Primiparous } & \multirow{3}{*}{$\leq 100$} & $\leq 5.50$ & 3135 & 1 & 32.4 & 360 & 2.08 \\
\hline & & $5.51-7.00$ & 1263 & 2 & 31.5 & 382 & 1.84 \\
\hline & & $>7.00$ & 420 & 3 & 30.6 & 388 & 1.81 \\
\hline & \multirow{3}{*}{$101-200$} & $\leq 5.50$ & 4084 & 4 & 33.1 & 370 & 2.20 \\
\hline & & $\overline{5} .51-7.00$ & 1978 & 5 & 31.8 & 373 & 2.07 \\
\hline & & $>7.00$ & 811 & 6 & 30.7 & 374 & 1.95 \\
\hline & $201-300$ & $\leq 5.50$ & 3959 & 7 & 31.6 & 361 & 2.20 \\
\hline
\end{tabular}




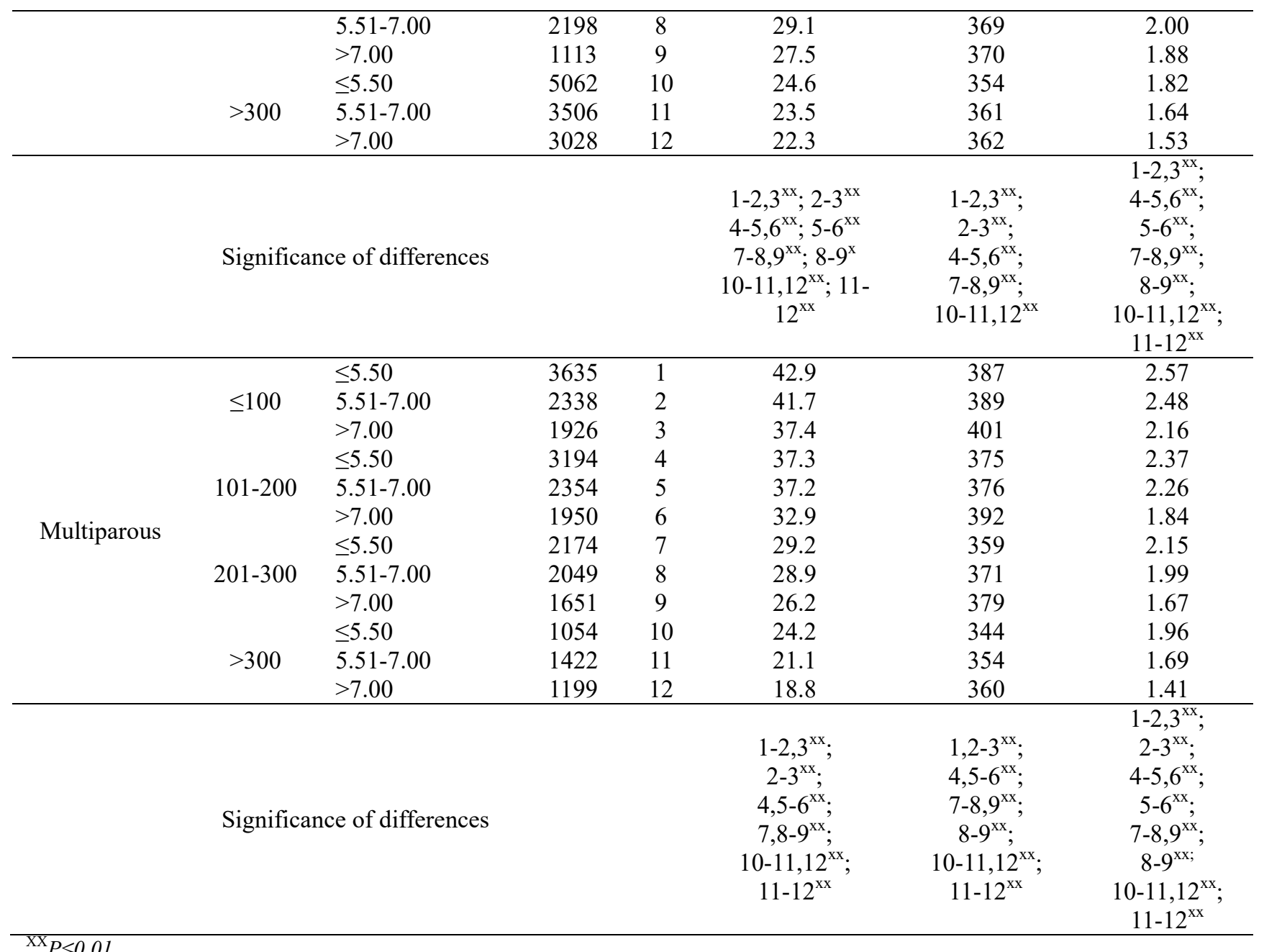

Table 4. Effect of milk electrical conductivity and daily milk yield on milkability of primiparous and multiparous cows.

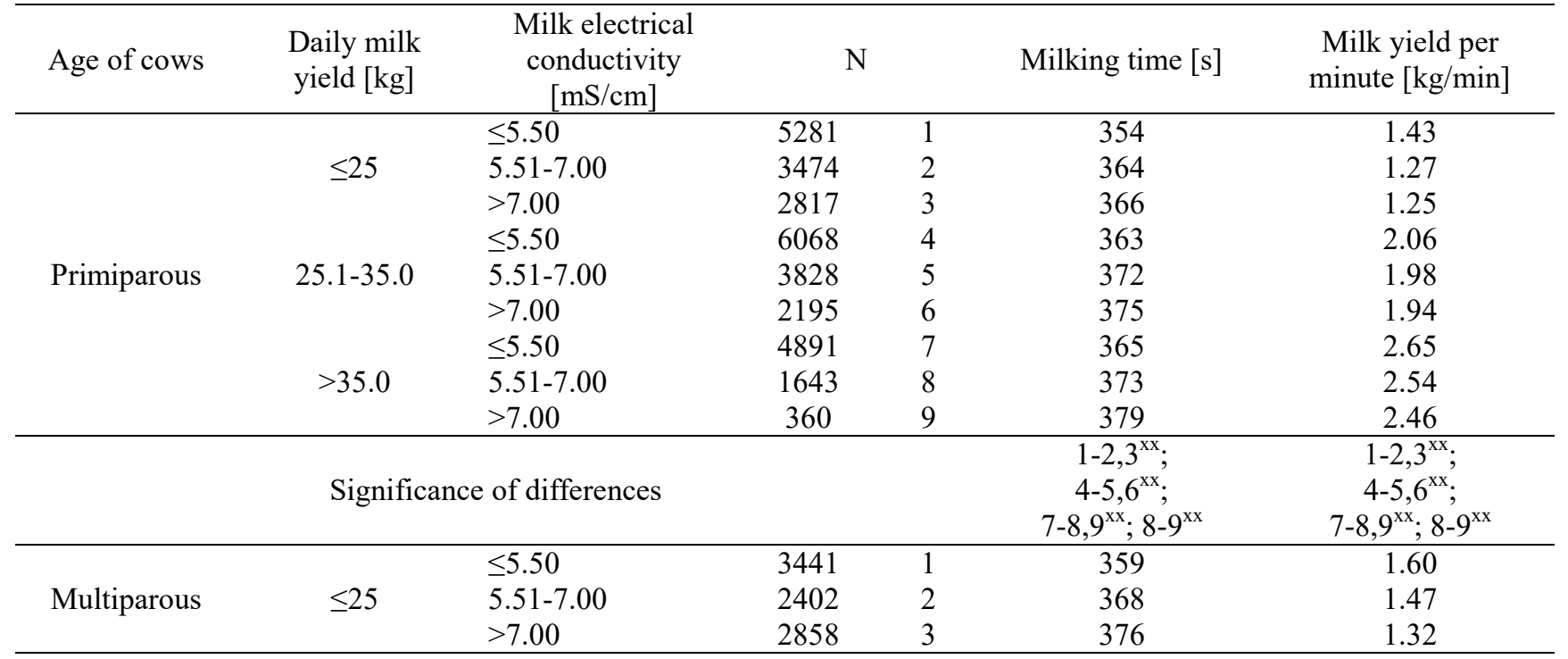




\begin{tabular}{clcccc}
\hline & $\leq 5.50$ & 4009 & 4 & 369 & 2.18 \\
\multirow{2}{*}{$25,1-35,0$} & $5.51-7.00$ & 2291 & 5 & 376 & 2.08 \\
& $>7.00$ & 1864 & 6 & 386 & 1.95 \\
& $\leq 5.50$ & 6607 & 7 & 380 & 2.76 \\
\multirow{2}{*}{$>35.0$} & $5.51-7.00$ & 3470 & 8 & 380 & 2.68 \\
& $>7.00$ & 2004 & 9 & 400 & 2.39 \\
\hline \multirow{3}{*}{ Significance of differences } & & & $1,2-3^{\mathrm{xx}} ; 2-3^{\mathrm{xx}} ;$ & $1-2,3^{\mathrm{xx}} ; 2-3^{\mathrm{xx}} ;$ \\
& & & $4,5-6^{\mathrm{xx}} ; 5-6^{\mathrm{xx}} ;$ & $4-5,6^{\mathrm{xx}} ; 5-6^{\mathrm{xx}} ;$ \\
& & & $7,8-9^{\mathrm{xx}}$ & $7-8,9^{\mathrm{xx}} ; 8-9^{\mathrm{xx}}$ \\
\hline
\end{tabular}

Conclusions: In summing up, it is concluded that throughout lactation, in both primiparous and multiparous cows, daily milk yield decreased with increasing electrical conductivity of the milk and thus with deteriorating udder health. Furthermore, milk electrical conductivity had a significant effect (in the interaction with lactation period and daily milk yield of the cows) on milkability traits (milking time and mean milk yield per minute).

The authors declare that they have no conflict of interest.

\section{REFERENCES}

Antanaitis, R., V. Zilaitis, V. Juozaitiene, V. Palubinskas, G. Kucinskas, A. Sederwicius, and D. Beliavska-Aleksiejune (2015). Efficient diagnostics and treatment of bovine mastitis according to herd management parameters. Vet. Med. Zoot. 69(91): 3-10.

Atasever, S., and H. Erdem (2009). Association between subclinical mastitis markers and body condition scores of Holstein cows in the Black Sea region. Turk. J. Anim. Vet. Adv. 8: 476-480.

Berglund, I., G. Petterson, K. Ostenddon, and K. Svennersten-Sjaunja (2007). Quarter milking for improved detection of increased SCC. Reprod. Domest. Anim. 42: 4237-4243.

Bogucki, M., and W. Neja (2008). Effect of selected factors on milking time and milking rate of dairy cows. Rocz. Nauk. PTZ 4(1): 55-59.

Bruckmaier R. M., C. E. Ontsouka, and J. W. Blum (2004). Fractionized milk composition in dairy cows with subclinical mastitis. Vet. Med. 49: 283-290.

Edwards, J. P., J. G. Jago, and N. Lopez-Villalobos (2014). Analysis of milking characteristics in New Zealand dairy cows. J. Dairy Sci. 97: 259269.

Forsbäck, L., H. Lindmark-Mänsson, A. Andren, M. Akerstedt, L. Andree, and K. SvennerstenSjaunja (2010). Day-to-day variation in milk yield and milk composition at the udder quarter level. J. Dairy Sci. 93: 3569-3577.

Hamann, J., and P. Gyodi (2000). Somatic cells and electrical conductivity in relation to milking frequency. Milchwissensch 55: 303-307.

Hillerton, J. E., and A. W. Walton (1991). Identification ofsubclinical mastitis with a hand-hold electrical conductivity meter. Vet. Rec. 128: 513-515.

Hillerton, J., and E. J. Semmens (1999). Comparison of Treatment of Mastitis by Oxytocin or Antibiotics Following Detection According to Changes in Milk Electrical Conductivity Prior to Visible Signs. J. Dairy Sci. 82: 93-98.

Hovinen, M., and S. Pyorala (2011). Invited review: udder health $\mathrm{f}$ dairy cows in automatic milking. J. Dairy Sci. 94: 547-562.

Ilie, L. I., L. Tudor, and A. M. Galis (2010). The electrical conductivity of cattle milk and the possibility of mastitis diagnosis in Romania. Med. Vet. 43(2): 220-227.

Jędruś, A. (2013). Modern milking systems in small barns. Hod. i Chów Bydła 6: 32-35.

Kasikci, G., O. Cetin, E. B. Bingol, and M. C. Gunduz (2012). Relations between electrical conductivity, somatic cell count, California mastitis test and some quality parameters in the diagnosis of subclinical mastitis in dairy cows. Turk. J. Vet. Anim. Sci. 36 (1): 49-55.

Larroque, H., R. Rupp, S. Moureaux, D. Boichard, and V. Ducrocq (2005). Genetic parameters for type and functional traits in the French Holstein breed. Interbull meeting, June 2-4, Uppsala, Sweden, 169-179.

Lee, D. H., and V. Choudhary (2006). Study on Milkability Traits in Holstein Cows. AsianAustralas. J. Anim. Sci. 19: 309-314.

Norberg, E. (2005). Electrical conductivity of milk as phenotype and genetic indicator of bovine mastitis. Liv. Prod. Sci. 96: 129-139.

Nowak, C., T. Grega, and E. Gardzina (1990). Detection of mastitis in cows through measurement of milk electrical conductivity. Zesz. Nauk. AR Kraków 235(8): 11-21.

Park, Y. W., M. Juarez, M. Ramos and G. F. W. Haenlein, (2007). Physico-chemical characteristics of goat and sheep milk. Small Rumin. Res. 68: 88-113.

SAS Institute Inc. 2017. SAS/STAT(r) 9.4 User/'s Guide. Cary, NC: SAS Institute Inc. 
Schepers, A. J., T. J. G. M. Lam, Y. H. Schukken, J. B. M. Wilmink, and W. B. A. Hanekamp (1997). Estimation of variance components for somatic cell counts to determine thresholds for uninfected quarters. J. Dairy Sci. 80: 1833-1840.

Sitkowska, B., D. Piwczyński, J. Aerts, and M. Waśkowicz (2015). Changes in milking parameters with robotic milking. Archiv. Anim. Breed. 57: 137-143.

Sivarajasingam, S., E. B. Burnside, J. W. Wilton, W. C. Pfeiffer, and D. G. Grieve (1984). Ranking
Dairy Sires by a Linear Programming Dairy Farm Model. J. Dairy Sci. 67: 3015-3024.

Weiss, D., M. Weinfurtner, and R. M. Bruckmairer (2004). Teat anatomy and its relationship with quarter and udder milk flow characteristics in dairy cows. J. Dairy Sci. 87: 3280-3289.

Yoshida, T., N. Lopez-Villalobos, and C. W. Holmes (2005). Relationships between milk yield, milk composition and electrical conductivity in dairy cattle. Proc. N.Z. Soc. Anim. Prod. 65: 143-147. 